Tuah Talino

Tahun XIV Volume 14 Nomor 2 Edisi 4 Desember 2020

ISSN 0216-079X E-ISSN 2685-3043

Balai Bahasa Kalimantan Barat

\title{
NILAI BUDAYA DAN EKSISTENSI SASTRA LISAN DAYAK GOLIK DI KABUPATEN SANGGAU
}

\section{CULTURAL VALUES AND EXISTENCE OF GOLIK ORAL LITERATURE IN SANGGAU}

\author{
Hari Purwiati \\ Balai Bahasa Kalimantan Barat \\ Jalan Ahmad Yani Pontianak \\ hpurwiati@gmail.com
}

\begin{abstract}
ABSTRAK
Penelitian ini bertujuan memperoleh gambaran utuh mengenai nilai budaya yang terkandung dalam sastra lisan Dayak Golik dan keberadaannya pada masa sekarang ini. Teori yang digunakan pada kajian ini adalah konsep nilai budaya. Nilai budaya berupa ide-ide yang mengonsepsikan hal-hal yang paling bernilai dalam tatanan kehidupan masyarakat. Suatu sistem nilai budaya terdiri atas konsepsi-konsepsi yang hidup dan tumbuh dalam alam pikiran sebagian besar warga masyarakat dan itupun berkaitan erat dengan hal-hal yang mereka anggap amat bernilai dalam hidup. Penelitian ini merupakan penelitian kualitatif dalam perpektif sastra. Pendekatan yang dipergunakan dalam penelitian ini adalah pendekatan budaya dan sosiologis. Pendekatan budaya digunakan untuk menganalisi nilai budaya pada teks cerita satra lisan Dayak Golik. Sementara itu, pendekatan sosiologis untuk menganalisis eksistensi sastra lisan pada masa sekarang ini di tengah masyarakat. Analisis data menunjukkan adanya beberapa nilai budaya yang terkandung dari dua sastra lisan yang dijadikan sampel. Pada sastra lisan yang berjudul Tujuh Bersaudara nilai budaya yang terkandung antara lain selalu berbuat baik kepada makhluk lain, sayang kepada saudara, tidak boleh iri hati, dan sabar dalam menghadapi cobaan. Sementara itu pada sastra lisan Gua Tangraya nilai budaya yang ada antara lain, sabar dalam menghadapi cobaan, membalas kejahatan dengan kebaikan, jangan terlalu tamak dalam hidup, dan menghormati tamu.

Kata kunci : sastra, lisan, nilai
\end{abstract}

\begin{abstract}
This study is entitled Cultural Values and the Existence of Oral Literature in Dayak Golik in Sanggau Regency. This study aims to obtain a complete picture of the cultural values contained in Dayak Golik oral literature and its existence at the present time. The theory used in this study is the concept of cultural values. Cultural values in the form of ideas that conceptualize most valuable in the fabric of people's lives. A cultural value system consists of conceptions that live and grow in the minds of most members of the community and that too is closely related to the things they consider to be very valuable in life. This research is a qualitative research in the literature perspective. The approach used in this study is a cultural and sociological approach. The cultural approach is used to analyze cultural values in the oral text of the Dayak Golik stories. Meanwhile, a
\end{abstract}


Tuah Talino

Tahun XIV Volume 14 Nomor 2 Edisi 4 Desember 2020

ISSN 0216-079X E-ISSN 2685-3043

Balai Bahasa Kalimantan Barat

sociological approach to analyzing the existence of oral literature at the present time in society. Data analysis shows that there are several cultural values which are contained from two oral literatures which are sampled. In the oral literature entitled The Seven Brothers, the value of bubaya contained includes always doing good to other creatures, pitying you, not being jealous, and being patient in facing trials. Meanwhile in the oral literature of Tangraya Cave the cultural values that exist include patience in facing trials, repaying evil with kindness, not being too greedy in life, and respecting guests.

Keywords: literature, oral, values

\section{PENDAHULUAN}

Sebagai bagian kebudayaan yang pernah hidup dan berkembang ditengahtengah kehidupan masyarakat, sastra lisan itu mempunyai fungsi dan kedudukan bagi penuturnya, seperti sebagai sarana penghibur, sarana pendidikan, dan sarana komunikasi. Bahkan Syahril (2018: 92) menjelaskan bahwa karya sastra baik lisan maupun tulisan tentunya mengandung ajaran, pesan, dan aturan yang terjadi dan berkembang serta berlaku pada masyarakat tersebut. Seiring dengan kemajuan dan perkembangan zaman, maka terjadi pula perubahan ditengahtengah masyarakat, tidak terkecuali masyarakat Dayak dan Melayu Kalimantan Barat. Perubahan ini berakibat pula perubahan pada keberadaan cerita rakyat ditengah-tengah masyarakat pendukungnya.

Ada beberapa faktor yang menyebabkan perubahan tersebut di antaranya, minat masyarakat terhadap sastra lisan mulai berkurang sehingga keberadaan cerita rakyat mulai terabaikan, mulai langkanya penutur cerita rakyat karena banyak yang telah lanjut usia bahkan sebagian telah meninggal dunia, kemasan dari cerita rakyat dalam penyajiannya, cerita rakyat haruslah memiliki daya tarik sehingga cerita rakyat khususnya dan sastra lisan pada umumnya bisa menjadi bacaan yang menarik dan menjadi tuntunan bagi penikmatnya, adanya pandangan masyarakat yang menganggap bahwa cerita rakyat sebagai bacaan kanak-kanak belaka (Musfeptial, dkk, 2019: 2). Padahal cerita rakyat tersebut banyak mengandung nilai-nilai moral yang berguna bagi masyarakat.

Mengingat hal tersebut di atas, pendataan dan pemetaan terhadap sastra lisan merupakan pekerjaan yang harus segera dilakukan sehingga hasilnya dapat dimanfaatkan untuk beberapa keperluan, diantaranya ; (1) bagi masyarakat perbatasan, agar dapat memahami dan menghayati warisan-warisan leluhur yang terdapat dalam sastra lisan, (2) sebagai bahan pembinaan dan pengembangan bahasa dan sastra daerah yang bagian dari sastra nasional, (3) sebagai bahan pengajaran apresiasi sastra daerah, dalam rangka memperkaya bahan pengajaran di lembaga pendidikan. Pemetaan, pendataan, dan pelestarian sastra lisan sangat penting untuk dilakukan untuk menjaga dari kepunahan dan perubahan. Sehingga kemudian hari, bangsa kita tidak kehilangan sebagian budaya nenek moyangnya. Persoalan yang kemudian akan muncul ketika sastra lisan tersebut hilang dan punah adalah sebagaimana yang diungkapkan oleh Amir, dkk. (2004: 1-2) bahwa punah dan hilangnya sastra lisan sebagian suku bangsa akan berdampak negatif pada masyarakat tersebut, antara lain masyarakat tersebut tidak akan mempunyai catatan sejarah, paling tidak rekaman budaya leluhurnya; mereka kehilangan 
Tuah Talino

Tahun XIV Volume 14 Nomor 2 Edisi 4 Desember 2020

ISSN 0216-079X E-ISSN 2685-3043

Balai Bahasa Kalimantan Barat

kecendekiawan nenek moyangnya; mereka kehilangan estetika masa lalunya, dan tidak kalah menakutkan adalah mereka tidak akan memiliki catatan sejarah. Solusi dari itu semua adalah kita semua harus segera memulai melakukan inventarisasi dan pemetaan terhadap sastra lisan tersebut.

Pada cerita rakyat, relasi antara isi cerita dengan sosial budaya masyarakat sangat kentara. Hal ini sangat masuk akal karena sebagai hasil karya kolektif cerita rakyat diciptakan selain untuk pelipur lara juga memiliki manfaat lain. Manfaat lain tersebut di antaranya sebagai pengukuhan sistem yang ada pada masyarakat penutur sastra lisan tersebut. Selain itu, sebagai ragam sastra lisan yang hidup, tumbuh, dan berkembang ditengah-tengah masyarakat, cerita rakyat juga mengandung banyak nilai budaya. Koenjaraningrat (1984: 26) mengatakan, nilai budaya adalah lapisan pertama dari kebudayaan yang ideal atau adat." Nilai budaya berupa ide-ide yang mengonsepsikan hal-hal yang paling bernilai dalam tatanan kehidupan masyarakat. Suatu sistem nilai budaya terdiri atas konsepsikonsepsi yang hidup dan tumbuh dalam alam pikiran sebagian besar warga masyarakat dan itu pun berkaitan erat dengan hal-hal yang mereka anggap amat bernilai dalam kehidupan. Hal ini sejalan dengan pendapat Nikmah (2013: 3) mengatakan bahwa karya sastra bukan semata-mata penyajian peristiwa yang indah melainkan juga penyampaian hakikat peristiwa tersebut. Dengan demikian, dapat dimaknai bahwa makna dibalik peristiwa dalam cerita tentu menjadi penting setelah peristiwa tersebut dihayati dan dilakukan penafsiran.

Memosisikan cerita rakyat sebagai cerita kanak-kanak belaka telah membuat cerita rakyat tanpa disadari terdegredasi pada tataran yang kemudian cerita rakyat menjadi tidak menarik dan menjadi seakan mengada-ngada. Padahal, cerita rakyat mengandung banyak nilai budaya yang seharusnya tetap dilestarikan. Bahkan nilai merupakan sebuah unsur yang penting pada kebudayaan (Juanda, 2019:163). Solusi dari itu semua adalah kita semua harus segera memulai melakukan inventarisasi, pelestarian, dan revitalisasi cerita rakyat.

Sesuai dengan latar belakang yang sudah diuraikan di atas, masalah pada penelitian ini adalah bagaimanakah nilai budaya pada sastra lisan masyarakat Dayak Golik dan eksisitensi sastra lisan pada masayarakat Dayak Golik dalam konsep pelestarian dan pemeliharaan sastra lisan. Kajian terhadap sastra lisan golik pernah dilakukan oleh Musfeptial dan Hari Purwiati (2019). Kajian tersebut lebih menitik beratkan pada pemetaan sastra lisan Dayak Golik. Artinya, kajian ini berbeda dengan apa yang telah dilakukan oleh peneliti sebelumnya.

Kerangka teori yang digunakan sebagai landasan dalam penelitian ini adalah konsep nilai budaya. Sebagai ragam sastra lisan yang hidup, tumbuh, dan berkembang ditengah-tengah masyarakat, cerita rakyat mengandung nilai-nilai budaya yang ada dalam masyarakat. Koenjaraningrat (1984: 26) mengatakan, nilai budaya adalah lapisan pertama dari kebudayaan yang ideal atau adat." Nilai budaya berupa ide-ide yang mengonsepsikan hal-hal yang paling bernilai dalam tatanan kehidupan masyarakat. Suatu sistem nilai budaya terdiri atas konsepsikonsepsi yang hidup dan tumbuh dalam alam pikiran sebagian besar warga masyarakat dan itupun berkaitan erat dengan hal-hal yang mereka anggap amat bernilai dalam hidup. Biasanya suatu sistem nilai budaya berfungsi sebagai 
Tuah Talino

Tahun XIV Volume 14 Nomor 2 Edisi 4 Desember 2020

ISSN 0216-079X E-ISSN 2685-3043

Balai Bahasa Kalimantan Barat

pedoman tertinggi bagi pola kelakuan, aturan-aturan, dan norma -norma dalam kehidupan . Sehingga suatu masyarakat akan terikat dengan suatu sistem nilai yang mereka anggap baik. Pelanggaran terhadap sistem nilai yang berlaku dalam suatu masyarakat oleh sekelompok orang atau individu, maka sangsi akan dijatuhkan kepada sekelompok orang atau individu yang melakukan pelanggaran tersebut.

Sebagai salah satu ragam sastra lisan, cerita rakyat merupakan bagian dari folklor lisan. Danandjaja ( 1991: 21) menjelaskan bahwa cerita rakyat merupakan bagian dari folklor lisan. Lebih lanjut Danandjaja membagi folklor atas tiga kelompok besar berdasarkan tipenya: (1) folklor lisan, (2) folklor sebagian lisan,(3) folklor bukan lisan. Folklor lisan dibagi atas beberapa bagian, yaitu bahasa rakyat, ungkapan tradisional, pertanyaan tradisional, puisi rakyat, cerita prosa rakyat, dan nyanyian rakyat. Sementara folklor sebagian lisan merupakan campuran unsur lisan dan unsur bukan lisan, seperti kepercayaan rakyat, permainan rakyat, teater rakyat, upacara, dan tari rakyat. Sedangkan folklor bukan lisan dibagi atas dua subkelompok, yaitu yang berupa material dan bukan material. Yang masik ke dalam ranah sastra lisan pada bagian ini adalah gabungan antara folklor lisan dan setengah lisan, antara lain ungkapan tradisional, pertanyaan tradisional, puisi rakyat, cerita prosa rakyat, teater rakyat, dan teks (lisan) upacara tradisional,

Yang dimaksud dengan sastra lisan di sini adalah cerita yang disebarluaskan dari mulut ke telinga, tersebar secara lisan dan diwarisi secara turun-temurun. Cerita rakyat setidak-tidaknya memeliki beberapa ciri, antara lain; pertama, terikat kepada lokasi tertentu, kedua, berhubungan dengan masa tertentu atau masa lampau, ketiga adanya partisipasi seluruh masyarakat. Sementara Fang (1999:3) menyebut cerita rakyat itu dengan prosa rakyat, yaitu sastra yang hidup ditengahtengah rakyat dan dituturkan secara lisan oleh tukang cerita dari satu generasi kepada generasi berikutnya.

Dilihat dari segi isi, cerita rakyat dapat dikelompokkan dalam tiga kelompok besar yaitu mite, legenda, dan dongeng (Bascom dalam Danandjaja 1991: 50). Mite adalah cerita prosa rakyat yang dianggap benar-benar terjadi serta dianggap suci oleh pendukungnya dan biasanya ditokohkan oleh dewa dan makluk setengah dewa. Sedangkan legenda adalah certita yang dianggap benar-benar terjadi oleh pendukungnya tapi tidak dianggap suci dan biasanya ditokohkan oleh manusia yang memiliki kekuatan yang luar biasa. Berlainan dengan mite dan legenda, dongeng adalah prosa yang oleh pendukungnya dianggap benar-benar tidak pernah terjadi.

Kehadiran cerita rakyat di tengah-tengah kehidupan masyarakat sangatlah mempunyai peranan yang penting. Ini dimungkinkan dengan nilai-nilai budaya yang terkandung di dalam cerita rakyat tersebut. Cerita rakyat mengandung gagasan dan ide dari masyarakat pendukungnya yang disampaikan secara lisan. Sehingga kajian yang mendalam dan serius terhadap cerita rakyat dianggap penting, karena dengan kajian ini kita tidak hanya mengetahui ide dan gagasan dari suatu masyarakat tapi kita juga dapat mengetahui pandangan hidup dan nilai kemasyarakatan yang dimiliki oleh suatu masyarakat. 
Tuah Talino

Tahun XIV Volume 14 Nomor 2 Edisi 4 Desember 2020

ISSN 0216-079X E-ISSN 2685-3043

Balai Bahasa Kalimantan Barat

\section{METODE}

\section{Pendekatan Penelitian}

Pendekatan yang dipergunakan dalam penelitian ini adalah pendekatan budaya dan sosiologis. Pendekatan budaya digunakan untuk menganalisi nilai budaya pada teks cerita satra lisan Dayak Golik. Sementara itu, pendekatan sosiologis untuk menganalisis eksisitensi sastra lisan pada masa sekarang ini di tengah masyarakat. Ratna (2006: 59) menjelaskan bahwa pendekatan ini berhubungan dengan eksisitensi manusia bagai makhluk sosial. Selain itu, Robert Escarpit dalam bukunya yang berjudul Sociologie De La Litterature. Pada buku tersebut Escarpit menjelaskan secara luas makna dari sosiologi sastra. Baginya pencipta sastra, baik penulis untuk sastra tulis maupun kelompok komunitas (anonim) kalau pada sastra tradisional dalam mencipta genre sastra tak bisa dilepaskan dari komunitasnya. Dengan demikian dapat dimaknai bahwa karya sastra milik masyarakat yang kaya nilai estetika dan etika. Maka proses pewarisan menjadi halyang penting dalam kajian.

Metode yang digunakan dalam penelitian ini adalah metode deskriptif analisis. Metode deskriptif analisis dilakukan dengan cara mendeskripsikan faktafakta yang didapat dan kemudian disusul dengan analisis terhadap fakta-fakta dan data yang sudah dimiliki (Ratna, 2006:53).

\section{PEMBAHASAN}

\section{Deskripsi Cerita Tujuh Bersaudara}

Ada suatu kerajaan yang dipimpin seorang raja yang mempunyai tujuh orang anak laki-laki. Kegemaran anak-anaknya ini adalah berburu ke hutan untuk mencari binatang. Bagi mereka, apa saja hasil buruan yang didapat tidak ada masalah,yang penting mereka mendapat hasil dalam berburu. Pada suatu hari mereka pergi pergi berburu ke tempat yang jauh karena di hutan yang dekat dengan tempat tinggal mereka sudah mulai jarang ada binatang. Setelah berjalan jauh, mereka belum juga mendapatkan binatang buruan. Namun demikian, tidak seberapa lama mereka melihat sebatang pohon yang di atasnya banyak bersarang burung. Pohon itu adalah pohon ketapang. Pohon ini aneh karena pangkalnya di langit dan pucuknya di dekat bumi. Tumbuh pohon ini terbalik dan terdapat banyak burung disitu.

Mereka mulai untuk berburu. Mereka mulai menembak burung di pohon itu. Maka semua bersiap mulai dari Si Sulung sampai Bungsu. Ternyata yang mencapai dahan pohon itu adalah sumpit Si Bungsu. Sesaat setelah sumpit mengenai dahan lalu keluarlah getah mengucur dari pohon dan akhirnya menjadi seutas tali besar yang menjuntai ke bawah. Dengan tali ini mereka bisa naik ke pohon itu. Sulung yang pertama naik, setelah beberapa saat naik sudah cukup tinggi lalu dia bertanya, "Sebesar apa aku dik?". "Sebesar kera", jawab adiknya. "Oh ternyata aku masih kelihatan", Lalu dia terus naik dan naik lagi, lalu dia bertanya kembali kepada adiknya, "Sebesar apa aku Dik?", "sebesar tupai” jawab adiknya. "Oh aku sudah nampak kecil ya", lalu dia takut untuk meneruskan naik lagi ke pohon itu dan dia turun kembali. Kemudian selanjutnya adalah giliran anak kedua untuk naik pohon itu dan dia juga melakukan hal yang sama dengan $\mathrm{Si}$ Sulung, setelah naik cukup tinggi lalu dia bertanya sebesar apa dia dan setelah 
Tuah Talino

Tahun XIV Volume 14 Nomor 2 Edisi 4 Desember 2020

ISSN 0216-079X E-ISSN 2685-3043

Balai Bahasa Kalimantan Barat

terlihat sebesar tupai turunlah dia, begitu seterusnya sampai pada giliran terakhir anak bungsu untuk naik ke pohon itu. Ketika Si Bungsu naik dia terus naik ke pohon itu dan dia bertanya, "sebesar apa aku Kak?", "sebesar Bonci", jawab abang-abangnya. Bonci adalah tupai yang kecil. "Oh aku masih kelihatan" Lalu dia naik terus ke pohon itu sampai tidak terdengar suarannya. Kemudian, dia naik ke pohon dan melihat banyak sekali burung. Berbagai macam jenis burung ada di situ, kemudian dia mulai menembak burung-burung itu dengan sumpit lalu berjatuhan burung-burung itu. Keenam abang yang berjaga di bawah tugasnya adalah mengumpulkan burung yang terjatuh.

Tanpa terasa hari sudah sore mereka mendapatkan buruan yang banyak sekali hari itu. Mereka membawa bagian masing-masing di pulang. Mereka merasa cemburu dengan adik bungsu yang berhasil mendapatkan buruan itu karena pasti si Bungsulah yang menjadi perhatian orang tuanya. Kemudian mereka mempunyai niat jahat kepada adik bungsu ini. Lalu dipotonglah tali yang tadi di pakai untuk memanjat ke atas pohon. Lalu sekejap tali itu hilang kembali lagi ke pohon. Si Bungsu yang masih ada di atas pohon tidak bisa lagi kemanamana apalagi mau turun dan kembali kerumah. Dia sudah ditinggalkan oleh abang-abangnya. Malam itu ia bermalam di sana hingga beberapa hari. Banyak sekali burung yang datang ke pohon itu. Lalu ada satu burung yang paling besar namanya burung enggang. Kemudian burung itu bertanya kepadanya, "Mengapa kamu di sini?" heran Si Bungsu, sebab ada burung yang bisa berbicara. Kemudian si bungsu bercerita mengapa dia bisa sampai ada di sana. Kemudian pahamlah burung enggang. "Oh seperti itu", kata Burung Enggang. "Baiklah nanti saya bantu, tapi biarkan aku makan dulu ya", kata Burung Enggang.

Setelah Burung Enggang makan dengan kenyang maka dia berkata kepada Si Bungsu, "sekarang kamu pukul-pukul badan saya ini supaya sayap ini bisa lepas dan rontok. Nanti kamu pakai sayapsaya yang lepas seperti pakai baju. Biarkan saja saya disini karena nanti sayap-sayap saya yang baru bisa tumbuh". Setelah dipukul-pukul oleh Si Bungsu maka lepaslah sayap itu dan dan disuruh Si Bungsu itu memakainya. "Ini sekarang kamu pakai, memakainya seperti baju biasa, ini bisa kamu pakai untuk terbang", kata Burung Enggang. Burung Enggang setelah sayapnya lepas lalu dicarikan tempat yang bagus untuk istirahat supaya cepat tumbuh bulu yang baru kembali. Si Bungsu telah memakai sayap pemberian Burung Enggang tadi lalu dia pakai untuk terbang. Dia tahu di manakerajaan tempat orang tua dia tinggal. Setelah terbang beberapa waktu lalu dia bertemu dengan kerajaan lain. Di kerajaan yang dia temui ada seorang bujang bernama Amang Lotur. Amang Lotur ini bertunangan dengan Dayang Putri Kumang. Kumang adalah seorang putri yang sangat cantik di kerajaan itu. Kumang bersama dengan kawannya pergi ke kebun tebu mereka. Mereka pergi dengan sampan ke hulu. Mereka juga ditemani oleh pembantunya yaitu Tengkulunong dan Tengkutobu. Setelah sampai di kebun tiba-tiba ada seekor burung. Burung itu tidak lain adalah Limangmusu atau Si Bungsu tadi. Mereka mengejar burung itu. Namun burung enggang itu diam saja tidak mau lari walaupun mereka semakin dekat. Akhirnya mereka tangkap. Setelah itu mereka mencari tebu lalu mereka pulang membawa burung itu. Tengkulunong di haluan dan Tungkutobu diburitan dan Kumang di tengah dekat dengan burung itu. 
Mereka pulang menghanyut dengan sampan. Ketika Kumang mengupas tebu dengan pisau tanpa sengaja pisau itu terlepas dari tangannya jatuh ke sungai, tapi burung itu dengan cekatan mengambil dengan paruhnya. Hal ini membuat penasaran Kumang dengan burung ini. Karena dia merasa sayang, maka di pelihara burung itu dirumahnya. Di rumah, Kumang ada juga tunangannya yaitu Abang Lontur. Setelah beberapa minggu berlalu, pada suatu malam ia keluar dari bajunya itu tadi, kemudian dia bilang pada Tengkulunong dan Tengkutobu,"coba kaliancari cabe, setelah itu nanti kalian hidupkan api di bawah ya dan bakarlah cabenya". Abang Lontur sedang tidur di luar asap dari cabe yang di bakar tercium maka dia batuk-batuk dan bersin-bersin. Merasa tidak mampu dia tinggal di situ lagi maka dia lari pulang. Kemudian di akhir, dikisahkan bahwa Si Bungsu atas izin jubata berubah wujud seperti manusia yang gagah dan membuat Dayang Putri Kumang jatuh cinta. Kemudian mereka berdua berumah tangga dan hidup baghagia.

\section{Deskripsi Cerita Asal-usul Gua Tangraya}

Tradisi suku Golik pada setiap akhir tahun adalah mengadakan gawai atau pesta. Di sebuah kampung yang terdapat di suku Golik sedang mengadakan pesta atau gawai yang dilaksanakan pada saat masa panen. Semua orang datang ke acara pesta gawai tersebut. Acara gawai sangatlah meriah penuh dengan kegembiraan. Pada acara itu datanglah seorang kakek dengan seorang cucu laki-lakinya. Setelah Kakek dan cucunya datang maka tuan rumah menyuguhkan hidangan, setiap hidangan yang di beri kepada kakek dan cucunya ini selau habis dalam waktu singkat, cepat sekali mereka habiskan. Kemudian diberi lagi tidak lama habis lagi begitu seterusnya.

Semakin lama persediaan makanan semakin berkuarang, namun anak ini tidak pernah kenyang. Setelah itu ada ide supaya anak ini bisa berhenti makan. Kemudian diambil kulat getah, kulat getah adalah getah torehan yang tidak di buat kepingan tetapi di bekukan sendiri di campur dengan kulit pohonnya kemudian diiris. Anak yang tidak bisa berhenti makan tadi di beri irisan kulit getah tadi kemudian di makan, namun setelah dimakan dia baru merasa aneh karena kulat getah itu tidak pernah putus walaupun di gigit, tetapi dia terus saja menggigit kulit getah itu.

Melihat cucunya seperti itu kakek itupun merasa kasihan. Ia merasa cucunya sedang dihina dan diolok-olok olah orang. Kemudian, kakek ini mengambil seekor anjing untuk dihias dan dipakaikan baju, supaya terlihat lucu. Setelah itu, disuruhnya anjing itu untuk berjalan keliling kampung. Melihat keanehan itu semua orang yang melihat menjadi tertawa terbahak-bahak. Tertawa berlebihan karena baru pertama melihat keanehan dan kelucuan itu. Setelah semua orang tertawa terbahak-bahak lalu di sekitar kampung itu mulai gelap dan datanglah awan hitam bersamaan dengan angin yang sangat kuat, disertai petir dan Guntur. Kemudian turunlah hujan, namun bukan hujan air seperti biasa tetapi hujan yang turun adalah hujan batu. Kejadian hujan batu itu di sebut dengan lobur artinya kampung yang kena hujan batu dan membentuk sebuah goa. Di dalam goa itu sampai sekarang bisa dilihat seperti ada meja makan dan tempat perapian dapur. 


\section{Nilai Budaya pada Sastra Lisan Dayak Golik Sastra Lisan Tujuh Bersaudara}

Pada sastra lisan Tujuh Bersaudara banyak nilai budaya yang dapat diuraikan pada pembahasan ini. Nilai budaya tersebut dapat diuraikan pada pembahasan berikut.

\section{Selalu Berbuat baik kepada Makluk Hidup}

Nilai budaya berbuat baik pada sesama dalam ceita ini tergambar dari sikap burung enggang yang membantu Si Bungsu yang ditinggalkan abangnya d atas pohon. Burung enggang berusaha menyelamatkan $\mathrm{Si}$ bungsu dengan cara melepaskan sayapnya. Lalu memberikan sayapnya kepada Si Bungsu. Hal tersebut seperti kutipan berikut.

Malam itu ia bermalam di sana hingga beberapa hari. Banyak sekali burung yang datang ke pohon itu. Lalu ada satu burung yang paling besar namanya burung enggang. Kemudian burung itu bertanya kepadanya, "Mengapa kamu di sini?" heran Si Bungsu, sebab ada burung yang bisa berbicara. Kemudian si bungsu bercerita mengapa dia bisa sampai ada di sana. Kemudian pahamlah burung enggang. "Oh seperti itu", kata Burung Enggang. "Baiklah nanti saya bantu, tapi biarkan aku makan dulu ya", kata Burung Enggang.

Setelah Burung Enggang makan dengan kenyang maka dia berkata kepada Si Bungsu, "sekarang kamu pukul-pukul badan saya ini supaya sayap ini bisa lepas dan rontok. Nanti kamu pakai sayapsaya yang lepas seperti pakai baju (Tujuh bersaudara, 2019:22).

Dari kutipan di atas tergambar bagaimana kebaikan seekor burung enggang. Ia mengorbankan sesuatu yang berharga di tubuhnya. Bagi burung enggang membantu sesama makhluk ciptaan Tuhan juga menjadi hal penting yang dilakukan. Si Bungsu menjadi bisa turun dari pohon tersebut. Bahkan sekarang Si Bungsu bisa terbang kemana-mana karena memakai sayap pemberian burung enggang.

\section{Sayang kepada Saudara}

Secara tersirat, enam saudara Si Bungsu berusaha meninggalkan Si Bungsu di dalam hutan ketika mereka pergi berburu. Tepatnya, ketika Si Bungsu sedang memanah burung dari atas pohon. Artinya, ada niat jahat dari enam saudara Si Bungsu. Dengan demikan, keenam saudaranya tidak memiliki rasa sayang kepada Si Bungsu. Hal ini terlihat seperti kutipan berikut.

Kemudian mereka mempunyai niat jahat kepada adik bungsu ini. Lalu dipotonglah tali yang tadi di pakai untuk memanjat ke atas pohon. Lalu sekejap tali itu hilang kembali lagi ke pohon. Si Bungsu yang masih ada di atas pohon tidak bisa lagi kemanamana apalagi mau turun dan kembali kerumah. Dia sudah ditinggalkan oleh abang-abangnya (Tujuh bersaudara, 2019:21) 
Tuah Talino

Tahun XIV Volume 14 Nomor 2 Edisi 4 Desember 2020

ISSN 0216-079X E-ISSN 2685-3043

Balai Bahasa Kalimantan Barat

Kepada saudara kandung seharusnya, keenam saudara Si Bungsu tidak berbuat jahat kepada. Akan tetapi, mereka melakukan kejahatan dengan cara membiarkan Si Bungsu tinggal di atas pohon sementara tali sebagai tempat naik dan turun sudah diputus oleh eam saudaranya. Nilai budaya dari kutipan ini jelas hendaknya kita selalu berbuat baik kepada saudara kita.

\section{Tidak Boleh Iri Hati}

Nilai budaya tidak boleh iri hati tergambar secara tersirat dari sikap keenam saudara Si Bungsu. Mereka iri hati atas keberhasilan S Bungsu memanah burung dari atas pohon. Itu terlihat dari kutipan berikut.

Mereka merasa cemburu dengan adik bungsu yang berhasil mendapatkan buruan itu karena pasti si Bungsulah yang menjadi

perhatian orang tuanya (Tujuh bersaudara, 2019:21).

Dari uraian diatas dapat dimaknai bahwa rasa iri keenam kakak si Bungsu karena dia mampu mendapatkan burung dari atas pohon. Keenam saudara Si Bungsu takut nantinya kedua orang tua mereka bertambah sayang kepada $\mathrm{Si}$ Bungsu.

\section{Sabar dalam menghadapi cobaan}

Pada cerita dikisahkan bahwa tokoh rekaan Si Bungsu sangat sabar dalam menghadapi cobaan. Ia hanya pasrah atas kezaliman yang dilakukan oleh keenam saudaranya. Artinya, ada nilai budaya sabar yang diperlihatkan oleh tokoh rekaan Si Bungsu. Dari kesabaran tersebut Si Bungsu akhirnya memperoleh sebuah solusi. Adanya seekor burung enggang yang rela membantu dan menyelamatkannya dari kejahatan saudaranya. Hal itu tergambar pada kutipan berikut.

"Mengapa kamu di sini?" heran Si Bungsu, sebab ada burung yang bisa berbicara. Kemudian si bungsu bercerita mengapa dia bisa sampai ada di sana. Kemudian pahamlah burung enggang. "Oh seperti itu", kata Burung Enggang. "Baiklah nanti saya bantu, tapi biarkan aku makan dulu ya", kata Burung Enggang(Tujuh bersaudara, 2019:21)

\section{B. Sastra Lisan Gua Tangraya}

Pada sastra lisan Gua Tangyara, ada tiga nilai budaya yang dapat diuraikan pada pembahasan ini. Nilai buday tersebut dapat diuraikan pada pembahasan berikut.

\section{Sabar dalam meghadapi cobaan}

Pada dikisahkan bahwa tokoh rekaan cucu diberi hidangan getah karet yang menyerupai daging. Melihat cucuknya sangat kepayahan dalam menggigit karet tersebut, kakek sangat merasamarah dan kesal. Hal tersebut terurai dalam kutipan berikut.

Melihat cucunya seperti itu kakek itupun merasa kasihan. Ia merasa cucunya sedang dihina dan diolok-olok olah orang. Kemudian, kakek ini mengambil seekor anjing untuk dihias dan dipakaikan baju, supaya terlihat lucu. Setelah itu, disuruhnya anjing itu untuk berjalan keliling kampung. Melihat keanehan itu semua orang yang melihat menjadi tertawa terbahak-bahak. 
Tertawa berlebihan karena baru pertama melihat keanehan dan kelucuan itu. Setelah semua orang tertawa terbahak-bahak lalu di sekitar kampung itu mulai gelap dan datanglah awan hitam bersamaan dengan angin yang sangat kuat, disertai petir dan Guntur. Kemudian turunlah hujan, namun bukan hujan air seperti biasa tetapi hujan yang turun adalah hujan batu (Gua Tangraya, 2019: 35).

Dari kutipan di atas terlihat bagaimana tokoh rekaan Kakek kurang sabar menghadapi ujian. Dia tidak sabar melihat cucunya diolok orang dengan kulit getah yang menyerupai daging yang susah digigit. Kakek berusaha membalas dengan cara lain. Artinya, sang kakek tidak sabar dalam menghadapi cobaan. Seharusnya sebagai orang yang sudah tua, kakek harus bersikap sabar dalam menghadapi cobaan hidup.

\section{Membalas kejahatan dengan Kebaikan}

Nilai budaya yang selanjutnya ada pada cerita ini adalah membalas kejahatan dengan nilai kebaikan. Nilai ini dapat diambil secara tersirat dari sikap kakek. Kakek tidak bijak menyikapi cobaan yang menmpa cucunya. Hal iu seperti kutipan berikut.

Melihat cucunya seperti itu kakek itupun merasa kasihan. Ia merasa cucunya sedang dihina dan diolok-olok olah orang. Kemudian, kakek ini mengambil seekor anjing untuk dihias dan dipakaikan baju, supaya terlihat lucu. Setelah itu, disuruhnya anjing itu untuk berjalan keliling kampung. Melihat keanehan itu semua orang yang melihat menjadi tertawa terbahak-bahak. Tertawa berlebihan karena baru pertama melihat keanehan dan kelucuan itu. Setelah semua orang tertawa terbahak-bahak lalu di sekitar kampung itu mulai gelap dan datanglah awan hitam bersamaan dengan angin yang sangat kuat, disertai petir dan Guntur. Kemudian turunlah hujan, namun bukan hujan air seperti biasa tetapi hujan yang turun adalah hujan batu. Kejadian hujan batu itu di sebut dengan lobur artinya kampung yang kena hujan batu dan membentuk sebuah goa. Di dalam goa itu sampai sekarang bisa dilihat seperti ada meja makan dan tempat perapian dapur (Gua Tangraya, 2019: 35).

Dari kutipan di atas dapat dimaknai bahwa melihat penghinaan kepada cucunya, Kakek membalas kejahatan orang dengan kejahatan juga. Sehingga kampung itu kemudian berubah jadi gua yang bernama Gua Tangraya.

\section{Jangan terlalu tamak dalam hidup}

Dalam hidup jangan terlalu tamak atau rakus. Ketamakan akan membuat diri kita diolok oleh orang lain. Hal itu seperti yang menimpa cucu kakek, seperti kutipan berikut.

Setiap hidangan yang di beri kepada kakek dan cucunya ini selau habis dalam waktu singkat. Cepat sekali mereka habiskan. 
Tuah Talino

Tahun XIV Volume 14 Nomor 2 Edisi 4 Desember 2020

ISSN 0216-079X E-ISSN 2685-3043

Balai Bahasa Kalimantan Barat

Kemudian diberi lagi tidak lama habis lagi begitu seterusnya (Gua Tangraya, 2019: 36).

\section{Menghormati Tamu}

Menghormati tamu merupakan suatu keharusan. Nilai ini memjadi penting diungkap pada cerita sebab kakek bersama cucunya merasa terhina karena cucunya dihidangkan getah yang sudah dicampur kulit kayu. Hal itu terungkap seperti kutipan berikut.

Kemudian diambil kulat getah, ulat getah adalah getah torehan yang tidak dibuat kepingan tetapi dibekukan sendiri di campur dengan kulit pohonnya kemudian diiris. Anak yang tidak bisa berhenti makan tadi diberi irisan kulit getah tadi. Kemudian dimakannya. Akan tetapi, setelah dimakan dia baru merasa aneh karena kulat getah itu tidak pernah putus walaupun di gigit, tetapi dia terus saja menggigit kulit getah itu (Gua Tangraya, 2019: 36).

Dari kutipan di atas terlihat bagaimana sikap tuan rumah. Tidak sepantasnya tuan rumah menghidangkan torehan getah yang sudah dicampur dengan kulit kayu dan dibekukan. Sebagai tuan rumah seharusnya dia memuliakan tamu sebagai orang yang dihormati.

\section{Eksistensi Sastra Lisan Pada Masyarakat Dayak Golik.}

Eksistensi dimaknai keberadaan sastra lisan pada saat ini di masayarak Dayak Golik. Ini penting untuk dilihat dalam sudut penyelamatan sastra lisan Dayak Golik. Dari data yang didapat di lapangan dapat disimpulkan bahwa dari dua cerita ini hanya judul cerita Gua Tangraya inilah yang diketahui oleh generasi muda. Akan tetapi, cerita utuh tentang Gua Tangraya sebagian besar mereka tidak mengetahuinya. Mengenalkan kembali sastra lisan kepada generasi muda merupakan suatu keharusan dalam rangka pelestarian nilai budaya kepada generasi muda. Dengan demikian, penyelamatan dan pelestarian sastra lisa Dayak Golik kepada generasi muda menjadi berkejanjutan dalam rangka penyelamatan aset budaya bangsa Indonesia.

\section{PENUTUP}

Pendataan dan penyelamatan teradap sastra lisan Dayak Golik merupakan pekerjaan yang harus segera dilakukan sehingga hasilnya dapat dimanfaatkan untuk beberapa keperluan, diantaranya; (1) bagi masyarakat perbatasan, agar dapat memahami dan menghayati warisan-warisan leluhur yang terdapat dalam sastra lisan, (2) sebagai bahan pembinaan dan pengembangan bahasa dan sastra daerah yang bagian dari sastra nasional, (3) sebagai bahan pengajaran apresiasi sastra daerah, dalam rangka memperkaya bahan pengajaran di lembaga pendidikan. Secara umumada beberapa nilai budaya yang terkandung dari dua sastra lisan yang dijadikan sampel. Pada sastra lisan yang berjudul Tujuh Bersaudara nilai budaya yang terkandung antara lain selalu berbuat baik kepada makhluk lain, sayang kepada saudara, tidak boleh iri hati, dan sabar dalam menghadapi cobaan. Sementara itu pada sastra lisan Gua Tangraya nilai budaya 
Tuah Talino

Tahun XIV Volume 14 Nomor 2 Edisi 4 Desember 2020

ISSN 0216-079X E-ISSN 2685-3043

Balai Bahasa Kalimantan Barat

yang ada antara lain, sabar dalam menghadapi cobaan, membalas kejahatan dengan kebaikan, jangan terlalu tamak dalam hidup, dan menghormati tamu.

Keberadaan sastra lisan Golik perlu menadi perhatian. Setidaknya dari data yang didapat di lapangan disimpulkan bahwa dari dua cerita ini hanya judul cerita Gua Tangraya inilah yang diketahui oleh generasi muda. Akan tetapi, cerita utuh tentang Gua Tangraya sebagian besar mereka tidak mengetahuinya. Dengan demikian, mengenalkan kembali sastra lisan ini kepada generasi muda merupakan suatu keharusan dalam rangka pelestarian nilai budaya kepada generasi muda.

\section{DAFTAR PUSTAKA}

Amir, Adriyeti. (2004). Pemetaan Sastra Lisan Minangkabau. Padang: Universitas Andalas

Danandjaja, James. (1991). Folklore: Ilmu Gosip, Dongeng, dan lain-lain. Jakarta: Grafiti Pers.

Fang, Liaw Yock. (1993) Sejarah Kesusastraan Melayu Klasik I. Jakarta: Erlangga

Juanda. (2019). "Nilai Pendidikan dalam Cerita Rakyat dan Perannya Terhadap Pembentukan Karakter" Jurnal Lingua Volume XV, Nomor 2, 2019. ISBN 18299342.

Koentjaraningrat. (1984). Kebudayaan, Mentalitas, dan Pembangunan. Jakarta: Gram

Musfeptial \& Purwiati, H. (2019). "Pemetaan Sastra Lisan Dayak Golik,

Kecamatan Beduai, Sanggau". Laporan Penelitian .

Nikmah, Nailiya.2013. "Karya Sastra Berbahasa Banjar Salah Satu Upaya Pelestarian Bahasa Banjar" Makalah Dialog Bahasa dan Sastra Kalimantan di Banjarmasin 23-24 Oktober 2013.

Ratna, Nyoman Kutha. (2006). Teori, Metode, dan Teknik Penelitian Sastra. Yogyakarta: Pustaka Pelajar.

Syahril (2018). “ Cerita Rakyat Mas Merah :Kajian Resepsi Sastra"Jurnal Kandai.Volume 14, Nomor 1, Mei 2018. ISSN2527-5968 (online), 1907204X (print). 